\title{
The Use of Social Networks and the Need for Social Approval of People in the Fields of Law, Medicine, and Academia in Turkey
}

\section{Türkiye'de Hukuk, Tıp ve Akademi Alanlarındaki Kişilerin Sosyal Paylaşım Ağları Kullanımı ve Sosyal Onay İhtiyacı}

\author{
Sefer KALAMAN ${ }^{1 \oplus}$, Rifat BECERİKLİ
}

${ }^{1}$ Asst. Prof. Dr., Ankara Yıldırım Beyazit University, Faculty of Humanities and Social Sciences, Department of Media and Communication, Ankara, Turkey

${ }^{2}$ Asst. Prof. Dr., Bozok University, Faculty of Communication, Department of Radio, Television, and Film, Yozgat, Turkey

ORCID: S.K. 0000-0002-2761-1229;

R.B. $0000-0001-6392-8330$

Sorumlu yazar/Corresponding author: Sefer Kalaman,

Ankara Yıldırım Beyazıt Üniversitesi, İnsan ve Toplum Bilimleri Fakültesi, Medya ve İletişim Bölümü, Ankara, Türkiye

E-posta/E-mail: skalaman@ybu.edu.tr

Geliş tarihi/Received: 17.09.2019 Revizyon talebi/Revision Requested: 10.10.2019

Son revizyon teslimi/Last revision received: 18.12 .2019

Kabul tarihi/Accepted: 10.02 .2020

Online yayın/Online published: 30.04 .2020

Atıf/Citation: Kalaman, S., Becerikli, R. (2020). The use of social networks and the need for social approval of people in the fields of law, medicine, and academia in turkey. Connectist: Istanbul University Journal of Communication Sciences, 59, 219-235. https://doi.org/10.26650/CONNECTIST2020-0049

\begin{abstract}
The aim of this study is to determine the level of social approval needs of people working in law, medicine, and academia, which are the most prestigious professions in Turkey, and whether there is a difference in the need for social approval among people who use and do not use social networks. The method used for obtaining data in this study was that of survey method. The universe of the study consists of about 334 thousand people who hold the profession of Judge, Lawyer, Doctor, Professor or Research Assistant in Turkey. The sample represented in this study comes from 1,509 people, who are judges, lawyers, doctors, professors and research assistants and living in 26 cities in Turkey. Kruskal-Wallis test, MannWhitney $\mathrm{U}$ test, Kolmogorov-Smirnov test, and Frequency Analysis were used in the analysis of the data. According to the results obtained from the analysis of the data, the social approval needs of the participants are low. In addition, the social approval needs of the participants varies greatly depending on their profession, age and gender. Furthermore, participants who use social networks need more social approval than those who do not.
\end{abstract}

Keywords: Social networks, internet, social approval, Turkey, profession

Öz

Çalışmanın amacı, Türkiye'deki en itibarlı meslek alanları olan hukuk, tıp ve akademi alanlarında çalışan bireylerin sosyal onaya ne düzeyde ihtiyaç duyduklarını ve sosyal paylaşım ağlarını kullanan ve kullanmayan bireyler arasında sosyal onay ihtiyacı noktasında bir farklılık olup olmadığını ortaya çıkarmaktır. Araştırmada verileri elde etmek için anket yöntemi kullanılmıştır. Araştırmanın evrenini, Türkiye'de hakim, avukat, doktor, profesör ve araştırma görevlisi mesleğini icra eden yaklaşık 334 bin kişi oluşturmaktadır. Türkiye'nin 26 şehrinde yaşayan 1509 kişi, hakim, avukat, doktor, profesör ve araştırma görevlisi ise araştırmanın örneklemini temsil etmektedir. Verilerin analizinde Kruskal-Wallis 
test, Mann-Whitney $U$ test, Kolmogorov-Smirnov test ve Frequency Analysis kullanılmıştır. Verilerin analizinden elde edilen sonuçlara göre, katılımcıların sosyal onay ihtiyaçlar düşük olmaktadır. Bunun yanında katılımcıların meslekleri, yaşları ve cinsiyetleri ile sosyal onay ihtiyacı arasında anlamlı bir farklılık bulunmaktadır. Ayrıca sosyal paylaşım ağlarını kullanan katılımcılar kullanmayan katılımcılara göre daha fazla sosyal onaya ihtiyaç duymaktadır.

Anahtar Kelimeler: Sosyal ağlar, internet, sosyal onay, Türkiye, meslekler

\section{INTRODUCTION}

Social desirability is closely related to culture. Social desirability refers to the need for social affirmation and acceptance and the belief that this can be achieved through culturally acceptable and appropriate behavior (Marlowe, \& Crowne, 1961, p. 109). In this context, social desirability is the identification of a culturally acceptable and approved set of behaviors (Crowne, \& Marlowe, 1960, p. 354). Social desirability is also expressed as a tendency to present oneself in a way that makes one look positive/good in terms of culturally derived norms and standards (Ballard, Crino, \& Rubenfeld, 1988, p. 227; Ganster, \& Hennessey, 1983; Mick, 1996; Zerbe, \& Paulhus, 1987). People with high social desirability are more concerned with the thoughts of others (Crowne \& Marlowe, 1960, p. 354). Moreover, social desirability is based on the fact that it creates the pressure of social acceptability (Hays, Hayashi, \& Stewart, 1989, p. 630). In this context, social desirability indicates the tendency to distort the social field according to one's own evaluation (Furnham, 1986, p. 385). In other words, such people are trying to interpret the person, events, and situations in the way that the social sphere wants. Social desirability is often seen as a tendency for people to present themselves positively, regardless of their'true feelings' about a subject (Holtgraves, 2004, p. 161; Moorman \& Podsakoff, 1992, p. 132). However, it is also emphasized that social desirability often occurs during social interaction (Johnson, Fendrich, \& Mackesy-Amiti, 2012, p. 1884).

High social desirability demonstrates that the normative social impact of the group in which the people are involved is also high (Martin \& Greenstein, 1983, p. 644). For example, if a person thinks that everyone in the peer group is against gay rights, s/he naturally believes that anti-gay rights are socially desirable (Bursztyn, \& Jensen, 2017, p. 148).

Given that people behave in both conscious and unconscious ways, social desirability can also be divided into two categories. It can be classified as unconscious behavior to enhance one's self-image and conscious behavior to show one's self-image positively towards others (Ventimiglia, \& MacDonald, 2015, p. 490). According to a recent two- 
factor model of socially desirability, in self-deception, the person believes in positive thinking in accordance with the accepted culture, and in impression management, the person deliberately creates a culture-appropriate image by not believing it (Ellingson, Sackett, \& Hough, 1999, p. 156; Paulhus, 1984).

Another concept encountered in social desirability research is the need for approval. Marlowe and Crowne (1961) describe social desirability as a need for social approval by saying that this can be achieved through culturally acceptable behaviors. In this respect, the concept of social desirability has evolved over the years into the concept of the need for approval in similar studies. Social approval refers to behaviors of thought that are appropriate and culturally accepted (Marlowe, \&Crowne, 1961, p. 109). The need for approval has two factors: a motive to approach-approval and a motive to avoid disapproval (Crowne, \& Marlowe, 1964). In other words, the "need for approval" is a combination of approval of the approach to the social one and the idea of avoidancewithdrawal from the non-social one (Millham, 1974, p. 379). The need for approval has also been conceptualized as representing sensitivity to social oppression and vulnerability (Ramanaiah, Schill, \& Leung, 1977, p. 251). People with a high need for social approval tend to self-assess in a culturally approved way (Buckhout, 1965, p. 127; Smith, \& Flenning, 1971, p. 383; Strickland \& Crowne, 1962); for this reason, people with a major need of approval, in this respect, care too much about what other people think (Holden, \& Fekken, 1989, pp. 184-187; Ross, \& Mirowsky, 1984, p. 189; Twenge, 2006, p. 173). However, it is also emphasized that social approval can be a form of avoidance of punishment (Strickland, \& Crowne, 1962). For example, it serves the function of precaution against the punishment of excluding or isolating the person from the social sphere.

Social desirability and the need for approval can also be regarded as universal concepts based on strong intercultural connections (Johnson, \& Vijver, 2002, p.197). In this regard, there is a distinction between cultures on earth. According to several studies, societies in the world, in general, are divided into two, namely, collective and individualistic. People in collective cultures pay particular attention to their relationships with other people (Triandis, 2001, p. 909; Twenge, \& Im, 2007, p. 187).Those in collective cultures express socially desirable answers to maintain good relationships with other people (Lalwani, Shavitt, \& Johson, 2006).

In many Asian cultures, society emphasizes joining others with a mutual harmony (Markus \& Kitayama, 1998). This harmony is prominent in family relationships. In the 
East, concepts such as compliance with others, obedience to parents, respect for parents, respect for ancestors, and financial support of parents are important (Triandis, 1995, p. 21). In other words, in collectivist cultures, the self is perceived as a sum of collective unity - family, tribe, religious group, etc. (Gelfand, Triandis, \& Chan, 1996, p. 399). In societies where there is collective unity, it is significant for other people evaluate behavior appropriately (Suh, Diener, Oishi, \&Triandis, 1998, p. 483). By way of example, people in Asian countries from collective cultures are in need of more social approval (Middleton, \& Jones, 2000; Twenge, 2006, p. 173).

There is both high uncertainty avoidance and low individuality in Near Eastern countries, including Turkey (Ronen, \& Shenkar, 1985, p. 451). It is stated in various studies that in Turkey the level of individualism is medium and the level of uncertainty avoidance is high (Johnson, Kulesa, Cho, \& Shavitt, 2005, p. 269). Turkey is shown to be among the collectivist societies/ collectivist cultures of the world (Suh et al., 1998; Triandis, 1993, p. 177).

The social approval needs of people living in a collective or individualistic culture environment can be shaped by the characteristic structure of the countries in which they live and the cultures to which they belong. Apart from this, the individual's internet and social media usage habits can influence the increase or decrease of their social approval needs. Indeed, there have been many studies of people's use of social media in recent years. For example; self-presentation (Chua, \& Chang, 2016; Herring, \& Kapidzic, 2015; Hogan, 2010), self-presentation and belonging on Facebook (Seidman, 2013), self-esteem social networking sites (Wilson, Fornasier, \& White, 2010), narcissism, extraversion and neuroticism (Amichai-Hamburger, \&Vinitzky, 2010), the need to belong, the need for self-presentation (Nadkarni, \& Hofmann, 2012), influence of personality on Facebook usage (Moore, \& McElroy, 2012). However, the relationship between the presentation and expression of people on social media with social desirability in the social sphere has not been adequately investigated. In other words, there are not many studies that measure the relationship between the need for social approval and social media. Likewise, studies examining the relationship between people's professions and the need for social approval are rare and hard to find. In this study, we examined the social approval needs of people in Turkey in the light of whether or not social approval needs change according to professions. We also investigated how far the use of social media affects social approval. 


\section{AIM AND METHODOLOGY}

\section{Aim}

People wish to be accepted by others by their actions and words, by the attitudes they adopt and by the existence they create both physically and mentally in private as well as public spheres. Whether this expectation, that is, social approval, takes place or not results in the individual's influence of being either positive or negative. The frequent repetition of this condition gives rise to the need for social approval within the individual and in turn becomes habitual or motor behavior. The use of social networks contributes to this need of the individual and causes people who use social networks to need social approval more than other individuals. The aim of this study is to determine the level of social approval required by individuals working in law, medicine, and academia, all of which are highly prestigious professions in Turkey. The study also aims to determine whether or not there is a difference in the need for social consent between individuals who use and do not use social networks. In accordance with the purpose of the study, the following research questions were asked:

RQ1: To what level do employees in law, medicine, and academia in Turkey need social media approval?

RQ2: In regard to social approval needs is there a difference between the various professional fields?

RQ3: Is there a meaningful relationship between the use of social networks and the need for social approval?

RQ4: Does the need for social approval differ according to demographic characteristics?

\section{Methodology}

A survey method was used to obtain data for this study. The study which was carried out in Turkey is important because it determines how social networks change a person's mental existence and daily life and/or prepare the ground for this by increasing social approval needs. Our study creates data for other scientific studies to be carried out. In the literature, it can be observed that there has not yet been a study related to social networks in Turkey regarding the need for social approval covering the fields of law, medicine, and academia. It is thought that the study will contribute to the literature in 
that it includes a large theoretical literature review on the need for social approval and also it is the first of its kind in Turkey.

About 334 thousand people (12,006 judges, 106,000 lawyers, 144,827 doctors, 24,640 professors, 45,998 research assistants) who work in the fields of law, medicine and academia in Turkey and carry out the professions of judges, lawyers, doctors, professors and research assistants constitute the universe of the study. The sample is determined based on the IBBS (classification of statistical region units) which is formed by the State Planning Organization (DPT) and the Turkish Statistical Institute (TÜIK) at three different levels and using stratified sampling method. The sample of the study consists of 1509 judges, lawyers, doctors, professors and research assistants who live in 26 sub-regions/cities in 12 regions of Turkey. The number of judges, lawyers, doctors, professors and research assistants of the 26 provinces in which the survey was conducted was examined and 1509 surveys were distributed proportionally based on the number of people in those provinces.

\section{Measures}

Field research was conducted to determine the level of social approval needs of judges, lawyers, doctors, professors and research assistants working in the fields of law, medicine and academia in Turkey. The survey was conducted between December 2018 and February 2019 and the data was obtained using the online survey method with participants. In the type of research which we conducted, the Marlowe Crowne scale has shown that social desirability in offline, online, and paper surveys is practically the same (Dodou, \& De Winter, 2014; Vésteinsdóttir, Reips, Joinson, \& Thorsdottir, 2015). The social approval scale of Karaşar and Öğülmüş (2016) was used while the survey was prepared. The social approval scale consists of 3 factors and 25 questions in total (1=strong disagreement; $5=$ strong agreement). The data from the survey was tested on Cronbach's Alpha for the reliability of the study and concluded that the study was highly reliable based on the value $(0,916)$ obtained. Kruskal-Wallis test, Mann-Whitney U test, KolmogorovSmirnov test, and Frequency Analysis were used in the analysis of the data.

\section{FINDINGS}

Data from the participants in the survey were analyzed both in the general framework and in 3 sub-dimensions (sensitivity to the judgments of others, social withdrawal, 
positive impression) at the point of need for social approval. It was determined that the minimum score that participants can get from the scale was 25 and the maximum score was 125 , while the midpoint was 75 . In this regard, according to the overall score (68.02) taken from the scale, it is possible to say that participants' social approval needs are low (Table 1).

An analysis of the demographic information about the participants revealed that the ratio of female (47.4 percent) and male (52.6 percent) are close together, they are in the maximum range of 25-44 years ( 69.5 percent), their education levels are balanced and the most highly represented profession is that of doctor (43.6 percent) (Table 2).

When we examine the patterns of use of internet and social networks, it is seen that more than half (58.0 percent) use the internet for 3 hours, most use the internet for research and information (47.9 percent), most use a social network (66.7 percent) for up to 2 hours, and most use the social network to follow the agenda (44.1) (Table 3).

The Mann-Whitney U test and Kruskal-Wallis test showed that there was a relationship of 5 percent significance, depending on the demographic characteristics of the participants ' need for social approval. There is a significant difference in gender subdimension between male and female in terms of sensitivity to the judgment of others and positive impression. Men are more sensitive to the judgments of others than women, while women tend to leave more positive impressions than men. However, there is a significant difference in all lower dimensions between ages. As the individual's age increases, the need for social approval decreases. In other words, young participants need more social approval than other participants. There is no significant difference between education level and social approval. However, there is a significant difference between occupations in all sub-dimensions in the need for social approval. Judges need social approval the least, while doctors need it the most. Also, when the fields most in need of social approval are ranked, the field of medicine is ranked first, the field of the academia is second, and the field of law is the last (Table 4).

According to the Kruskal-Wallis test, there is a relationship between participants' level of social network use and their social approval needs with a level of 5 percent significance. Participants who use the Internet most often to enter social networks need more social consent than those who use the Internet most often for research and for getting information. However, participants who use social networks to follow their 
friends' shares or to share content need more social approval than participants who never use social networks. Likewise, participants who use at least one social network need more social approval than participants who never use the internet for social networking purposes (Table 5).

\section{DISCUSSION AND CONCLUSION}

In some studies people from different countries of the world were compared on the basis of social approval scale. In one such study, consisting of Malaysian, French and US participants, Malaysian participants were in need of high social approval while US participants were in need of low social approval (Owens, Pettijohn, \& Keillor, 2001). In the study on Danish, the USA, and Lebanese college students, while the highest need for social approval was seen in Lebanese students, the least was seen in Danish students (Consalvi, 1972, p. 365). In another study, South African students' social desirability score was higher than that of Canadian students, both as girls and boys (Mwamwenda, 1996). Mexican-Americans and Negroes scored significantly higher than Whites on the Marlowe-Crowne social desirability scale (Fisher, 1967). In these studies, the need for social approval of Eastern, Asian and developing countries was higher than in Western countries in general. On this point, in our study, we concluded that the social approval needs of people working in high-status fields such as law, medicine, and academia in Turkey are low.

In other studies, it was found that there is a direct relationship between the profession and social class of the individual and the need for social approval, and studies concluded that the need for social approval of individuals working in low-status jobs is greater and the need for social approval of individuals working in high-status jobs (Martin, \& Greenstein, 1983, p. 645; Ross, \& Mirowsky, 1984, p. 193). In addition, there is a difference among occupations regarding the need for social approval. Judges need social approval the least, while doctors need it most. Also, when the fields most in need of social approval are ranked, the field of medicine is ranked first, the field of the academia is second, and the field of law is the last.

The need for social approval also differs according to the demographic characteristics of the individuals. Men are more sensitive to the judgments of others than women, while women tend to leave more positive impressions than men. However, from a general perspective, there is no significant difference between men and women in the 
need of social consent. According to other studies in the literature, the need for social approval of men and women is close to each other (Klassen, Homstra, \& Anderson, 1975 , p. 450; Shrauger, 1972, p. 289). However, there are studies indicating that women are in need of social approval more than men (Becker, \& Dileo, 1973).

However, as the individual's age increases, the need for social approval decreases. In other words, young participants need more social approval than other participants. There is no significant difference between education level and social approval as can be seen by the fact that all of the participants who participated in the study have at least an undergraduate level of education, while more than half graduated from at least one graduate program. However, when other studies in the field are analyzed, it is observed that there is a relationship between the educational level and the need for social approval. According to the data, the need for social approval is inversely proportional to the educational situation, and as the educational situation increases, the need for social approval decreases (Johnson, \& Fendrich, 2002; Klassen, Homstra, \& Anderson, 1975, p. 450). In addition, it is found that there is a negative relationship between educational achievement and intelligence and the need for social approval (Evans, \& Forbach, 1982; Fisher, 1967, p. 474); Fisher, \& Parsons, 1962).

When the relationship between the use of social network and the need for social approval is analyzed, it can be seen that people who use social networks need social approval more than those who use them less. As the use of social media increases, the need for social approval also increases. According to a study on Facebook regarding the level of need for approval on Facebook, extraverts who are higher in need of approval may spend more time on Facebook (Steers et al., 2016, p. 290).

Peer-review: Externally peer-reviewed.

Conflict of Interest: The authors has no conflict of interest to declare.

Grant Support: The authors declared that this study has received no financial support.

\section{REFERENCES}

Amichai-Hamburger, Y., \& Vinitzky, G. (2010). Social network use and personality. Computers in Human Behavior, 26, 1289-1295. http://dx.doi.org/10.1016/j.chb.2010.03.018

Ballard, R., Crino, M. D., \& Rubenfeld, S. (1988). Social desirability response bias and the Marlowe-Crowne social desirability scale. Psychological Reports, 63, 227-237. https://doi.org/10.2466/pr0.1988.63.1.227 
Becker, G., \& Dileo, D. (1967). Scores on Rokeach's dogmatism scale and the response set to present a positive social and personal image. The Journal of Social Psychology, 71, 287-293. https://doi.org/10.1080/00224545.1967.9919791

Buckhout, R. (1965). Need for social approval and attitude change. The Journal of Psychology, 60, 123-128. https://doi.org/10.1080/00223980.1965.10545270

Bursztyn, L., \& Jensen, R. (2017). Social image and economic behavior in the field: Identifying, understanding, and shaping social pressure. Forthcoming in the Annual Review of Economics, 9, 131-153. https://doi. org/10.1146/annurev-economics-063016-103625

Chua, T., \& Chang, L. (2016). Follow me and like my beautiful selfies: Singapore teenage girls' engagement in selfpresentation and peer comparison on social media. Computers in Human Behavior, 55, 190-197. https://doi. org/10.1016/j.chb.2015.09.011

Consalvi, C. (1972). An item and factor analysis of Danish, Lebanese and United States college students' responses to the Marlowe-Crowne social desirability scale. Journal of Cross-Cultural Psychology, 3, 361-372. https://doi.org/10.1177/002202217200300405

Crowne, D. P., \& Marlowe, D. (1964). The approval motive: studies in evaluative dependence. New York, USA: Wiley.

Crowne, D. P., \& Marlowe, D. (1960). A new scale of social desirability independent of psychopathology. Journal of Consulting Psychology, 24(4), 349-354. https://doi.org/10.1037/h0047358

Dodou, D., \& De Winter F. (2014). Social desirability is the same in offline, online, and paper surveys: A metaanalysis. Computers in Human Behavior, 36, 487-495. https://doi.org/10.1016/j.chb.2014.04.005

Ellingson, J. E., Sackett, P. R., \& Hough, L. M. (1999). Social desirability corrections in personality measurement: issues of applicant comparison and construct validity. Journal of Applied Psychology, 84(2), 155-166. https:// doi.org/10.1037/0021-9010.84.2.155

Evans, R., \& Forbach, G. (1982). Intellectual ability correlates of the Marlowe-Crowne social desirability scale. Journal of Personality Assessment, 46, 59-62. https://doi.org/10.1207/s15327752.jpa4601_10

Fisher, G. (1967). The performance of male prisoners on the differences as a function of race and crime MarloweCrowne social desirability scale. Journal of Clinical Psychology, 23, 473-475. https://doi.org/10.1002/10974679(196710)23:4<473::AID-JCLP2270230423>3.0.CO;2-B

Fisher, M., \& Parsons T. (1962). The performance of male prisoners on the Marlowe-Crowne social desirability scale. Journal of Clinical Psychology, 18, 140-141. https://doi.org/10.1002/1097-4679(196204)18:2<140::AIDJCLP2270180209>3.0.CO;2-4

Furnham, A. (1986). Response bias, social desirability and dissimulation. Personality and Individual Differences, 7(3), 385-400. https://doi.org/10.1016/0191-8869(86)90014-0

Ganster, D. C., Hennessey, H. W., \& Luthans, F.(1983). Social desirability response effects: three alternative models. The Academy of Management Journal, 26(2), 321-331. https://doi.org/10.5465/255979

Gelfand, M., Triandis, H., \& Chan D. (1996). Individualism versus collectivism or versus authoritarianism? European Journal of Social Psychology, 26, 397-410. https://doi.org/10.1002/(SICI)1099-0992(199605)26:3\%3C397::AIDEJSP763\%3E3.0.CO;2-J 
Hays, R.D., Hayashi, T., \& Stewart, A.L. (1989). A five-item measure of socially desirable response set. Educational and Psychological Measurement, 49, 629-636. https://doi.org/10.1177\%2F001316448904900315

Herring, S. C., \& Kapidzic, S. (2015). Teens, gender, and self-presentation in social media. In J.D. Wright (Ed.), International encyclopedia of social and behavioral sciences (pp. 146-152).Oxford, UK: Elsevier Inc.

Hogan, B. (2010). The presentation of self in the age of social media: distinguishing performances and exhibitions online. Bulletin of Science, Technology \& Society, 30, 377-386. https://doi. org/10.1177/0270467610385893

Holden, R. R., \& Fekken, G. C. (1989). Three common social desirability scales: friends, acquaintances, or strangers? Journal of Research in Personality, 23(2), 180-191. https://doi.org/10.1016/0092-6566(89)90022-6

Holtgraves, T. (2004). Social desirability and self-reports: testing models of socially desirable responding. Personality and Social Psychology Bulletin, 30, 161-172. https://doi.org/10.1177/0146167203259930

Johnson, T. P., \& Fendrich, M. (2002). A validation of the Crowne-Marlowe social desirability scale. Retrieved from http://www.srl.uic.edu/publist/Conference/crownemarlowe.pdf

Johnson, T. P., \& van de Vijver F. J. R. (2002). Social desirability in cross-cultural research. In J. A. Harkness, F.J.R. van de Vijver \& P. Mohler (Eds.), Cross-cultural survey methods (pp. 193-209). New Jersey, USA: John Wiley \& Sons Inc.

Johnson, T. P., Fendrich, M., \& Mackesy-Amiti M. E. (2012). An evaluation of the validity of the Crowne-Marlowe need for approval scale. Quality Quantity, 46(6), 1883-1896. https://doi.org/10.1007/s11135-011-9563-5

Johnson, T., Kulesa, P., Cho, Y., \& Shavitt, S. (2005). The relation between culture and response styles evidence from 19 countries. Journal Of Cross-Cultural Psychology, 36, 264-277. https://doi. org/10.1177/0022022104272905

Karaşar, B., \& Öğülmüş, S. (2016). Sosyal onay ihtiyacı ölçeği: Geçerlik ve güvenirlik analizi. Ege Eğitim Dergisi, 17(1), 84-104

Klassen, D., Homstra R., \& Anderson P. (1975). Influence of social desirability on symptom and mood reporting in a community survey. Journal of Consulting and Clinical Psychology, 43, 448-452. https://doi.org/10.1037/ h0076863

Lalwani, A. K., Shavitt, S., \& Johnson, T. (2006). What is the relation between cultural orientation and socially desirable responding? Journal of Personality and Social Psychology, 90(1), 165-178. https://doi. org/10.1037/0022-3514.90.1.165

Markus, H., \& Kitayama, S. (1991). Culture and the self: implications for cognition, emotion, and motivation. Psychological Review, 98(2), 224-253. https://doi.org/10.1037/0033-295X.98.2.224

Marlowe, D., \& Crowne, D. P. (1961).Social desirability and response to perceived situational demands. Journal of Consulting Psychology, 25(2), 109-115. https://psycnet.apa.org/doi/10.1037/h0041627

Martin, H.J., \& Greenstein, T. N. (1983). Individual differences in status generalization: effects of need for social approval, anticipated interpersonal contact, and instrumental task abilities. Journal of Personality and Social Psychology, 45(3), 641-662. https://doi.org/10.1037/0022-3514.45.3.641 
Mick, D. G. (1996). Are studies of dark side variables confounded by socially desirable responding? The case of materialism. Journal of Consumer Research, 23(2), 106-119. https://doi.org/10.1086/209470

Middleton, K., \& Jones L. (2000). Socially desirable response sets: the impact of country culture. Psychology \& Marketing, 17, 149-163. https://doi.org/10.1002/(SICI)1520-6793(200002)17:2<149::AID-MAR6>3.0.CO;2-L

Millham, J. (1974). Two components of need for approval score and their relationship to cheating following. Journal of Research in Personality, 8(4), 378-392. https://doi.org/10.1016/0092-6566(74)90028-2

Moore, K., \& McElroy, J. (2012). The influence of personality on Facebook usage, wall postings, and regret. Computers in Human Behavior, 28, 267-274. https://doi.org/10.1016/j.chb.2011.09.009

Moorman, R. H., \& Podsakoff, P. M. (1992). A meta-analytic review and empirical test of the potential confounding effects of social desirability response sets in organizational behaviour research. Journal of Occupational and Organizational Psycbology, 65(2),131-149. https://doi.org/10.1111/j.2044-8325.1992.tb00490.x

Mwamwenda, T. (1996). Social desirability scores of South African and Canadian students. Psychological Reports, 78, 723-726. https://doi.org/10.2466/pr0.1996.78.3.723

Nadkarni, A., \& Hofmann, G. (2012). Why do people use Facebook? Personality and Individual Differences, 52, 243249. https://doi.org/10.1016/j.paid.2011.11.007

Owens, D., Pettijohn, C., \& Keillor, B. (2001). A Cross-cultural/cross national study of influencing factors and socially desirable response biases. International Journal of Market Research, 43, 1-19. https://doi. org/10.1177/147078530104300101

Paulhus, D. (1984). Two-component models of social desirability responding. Journal of Personality and Social Psychology, 46(3), 598-609. https://doi.org/10.1037/0022-3514.46.3.598

Ramanaiah, N. V., Schill, T., \& Leung, L. S (1977). A test of the hypothesis about thetwo-dimensional nature of the Marlowe-Crowne social desirability scale. Journal of Research in Personality, 11(2), 251-259. https://doi. org/10.1016/0092-6566(77)90022-8

Ronen, S., \& Shenkar, O. (1985). Clustering countries on attitudinal dimensions: a review and synthesis. The Academy of Management Review, 10, 435-454. https://doi.org/10.5465/amr.1985.4278955

Ross, C. E.,\& Mirowsky, J. (1984). Socially-desirable response and acquiescence in a cross-cultural survey of mental health. Journal of Health and Social Behavior, 25(2), 189-197. https://doi.org/10.2307/2136668

Seidman, G. (2013). Self-presentation and belonging on Facebook: How personality influences social media use and motivations. Personality and Individual Differences, 54, 402-407. https://doi.org/10.1016/j.paid.2012.10.009

Shrauger, J. (1972). Performance on the Marlowe-Crowne scale and its perceived purpose. Journal of Personality Assessment, 36, 287-290. https://doi.org/10.1080/00223891.1972.10119758

Smith, R. E., \& Flenning, F. (1971). Need for approval and susceptibility to unintended social influence. Journal of Consulting and Clinical Psychology, 36(3), 383-385. https://doi.org/10.1037/h0031104

Steers, M.L. N., Quist, M. C., Bryan, J. L., Foster, D. W., Young, C. M., \& Neighbors, C. (2016). I want you to like me: extraversion, need for approval, and time on Facebook as predictors of anxiety. Translational Issues in Psychological Science, 2(3), 283-293. https://doi.org/10.1037/tps0000082 
Strickland, B. R., \& Crowne, D. P. (1962). Conformity under conditions of simulated group pressure as a function of the need for social approval. The Journal of Social Psychology, 58, 171-181. https://doi.org/10.1080/00224 545.1962 .9712366

Suh, E., Diener, E., Oishi, S., \& Triandis, H. (1998). The shifting basis of life satisfaction judgments across cultures: emotions versus norms. Journal of Personality and Social Psychology, 74, 482-493. https://doi. org/10.1037/0022-3514.74.2.482

Sunar, L. (2015). Türkiye'de Çalışma Yaşamı ve Mesleklerin İtibarı. Retrieved from https://tyap.net/ mediaf/T\%C3\%BCrkiye-Mesleki-\%C4\%B0tibar-Skalas\%C4\%B1-Sunumu-Son.pdf

Triandis, H. C. (1995). Individualism \& Collectivism. New York, USA: Routledge Taylor \& Francis Group.

Triandis, H. C. (2001). Individualism-collectivism and personality. Journal of Personality, 69(6), 907-924. https:// doi.org/10.1111/1467-6494.696169

Triandis, H. C. (1993). Collectivism and individualism as cultural syndromes. Cross-Cultural Research, 27, $155-180$. https://doi.org/10.1177\%2F106939719302700301

Twenge, J. M., \& Im, C. (2007). Changes in the need for social approval, 1958-2001. Journal of Research in Personality, 41(1), 171-189. https://doi.org/10.1016/j.jrp.2006.03.006

Ventimiglia, M., \& MacDonald, D. A. (2012). An examination of the factorial dimensionality of the MarloweCrowne social desirability scale. Personality and Individual Differences, 52(4), 487-491. https://doi. org/10.1016/j.paid.2011.11.016

Vésteinsdóttir, V., Reips, D., Joinson, A., \& Thorsdottir, F. (2015). Psychometric properties of measurements obtained with the Marlowe-Crowne Social Desirability Scale in an Icelandic probability based Internet sample. Computers in Human Behavior, 49, 608-614. https://doi.org/10.1016/j.chb.2015.03.044

Wilson, K., Fornasier, S., \& White, M. (2010). Psychological predictors of young adults': Use of social networking sites. Cyberpsychology, Behavior, and Social Networking, 13, 173-177. https://doi.org/10.1089/ cyber.2009.0094

Zerbe, W. J., \& Paulhus, D. L. (1987). Socially desirable responding in organizational behavior: A reconception. Academy of Management Review, 12(2), 250-264. https://doi.org/10.5465/amr.1987.4307820 


\section{TABLES AND FIGURES}

Table 1: Social Approval Needs

\begin{tabular}{|l|c|c|}
\hline & \multicolumn{2}{|c|}{ Social Approval Needs } \\
\hline & Average & 78,90 \\
\hline Sensitivity to the judgments of others & 3,1562 & 59,21 \\
\hline Social withdrawal & 2,3685 & 64,58 \\
\hline Positive impression & 2,5833 & 68,02 \\
\hline General & 2,7208 & \\
\hline
\end{tabular}

Table 2: Demographic Characteristics $(\mathrm{N}=1509)$

\begin{tabular}{|l|l|c|c|}
\hline Variables & & N & \% \\
\hline \multirow{5}{*}{ Gender } & Woman & 716 & 47,4 \\
\cline { 2 - 4 } & Man & 793 & 52,6 \\
\hline \multirow{5}{*}{ Age } & $18-24$ & 103 & 6,8 \\
\cline { 2 - 4 } & $25-34$ & 575 & 38,2 \\
\cline { 2 - 4 } & $35-44$ & 473 & 31,3 \\
\cline { 2 - 4 } & $45-54$ & 224 & 14,8 \\
\cline { 2 - 4 } & $55-64$ & 100 & 6,6 \\
\cline { 2 - 4 } & $65+$ & 34 & 2,3 \\
\hline \multirow{5}{*}{ Education Level } & Undergraduate & 594 & 39,3 \\
\cline { 2 - 4 } & Graduate & 374 & 24,8 \\
\cline { 2 - 4 } & Doctoral & 541 & 35,9 \\
\hline \multirow{5}{*}{ Profession } & Profession & 658 & 43,6 \\
\cline { 2 - 4 } & Doctor & 50 & 3,3 \\
\cline { 2 - 4 } & Judge & 513 & 34,0 \\
\cline { 2 - 4 } & Lawyer & 112 & 7,4 \\
\cline { 2 - 4 } & Professor & 176 & 11,7 \\
& Research Assistant & & 2 \\
\hline
\end{tabular}


Table 3: Use of Internet and Social Networks $(\mathrm{N}=1509)$

\begin{tabular}{|c|c|c|c|}
\hline Variables & & $\mathbf{N}$ & $\%$ \\
\hline \multirow{5}{*}{ Daily Internet Use } & Less than 1 hour & 127 & 8,4 \\
\hline & $1-3$ hours & 748 & 49,6 \\
\hline & 4-6 hours & 474 & 31,4 \\
\hline & 7-9 hours & 130 & 8,6 \\
\hline & More than 9 hours & 30 & 2,0 \\
\hline \multirow{5}{*}{$\begin{array}{l}\text { The Purpose of Internet } \\
\text { Use }\end{array}$} & Entering Social Networks (Facebook, Instagram, etc.) & 509 & 33,7 \\
\hline & Researching and Getting Information & 723 & 47,9 \\
\hline & Surfing on the Internet & 185 & 12,3 \\
\hline & Playing Game & 35 & 2,3 \\
\hline & Other & 57 & 3,8 \\
\hline \multirow{6}{*}{$\begin{array}{l}\text { Number Of Social } \\
\text { Networks Used }\end{array}$} & 1 & 450 & 29,8 \\
\hline & 2 & 556 & 36,9 \\
\hline & 3 & 255 & 16,9 \\
\hline & 4 & 61 & 4,0 \\
\hline & More than 4 & 44 & 2,9 \\
\hline & Not Use & 143 & 9,5 \\
\hline \multirow{6}{*}{$\begin{array}{l}\text { Daily Use of Social } \\
\text { Networks }\end{array}$} & Less than 1 hour & 560 & 37,1 \\
\hline & $1-3$ hours & 648 & 43,0 \\
\hline & 4-6 hours & 140 & 9,3 \\
\hline & 7-9 hours & 21 & 1,4 \\
\hline & More than 9 hours & 5 & 0,3 \\
\hline & Not Use & 135 & 8,9 \\
\hline \multirow{6}{*}{$\begin{array}{l}\text { The Purpose of Using } \\
\text { Social Networks }\end{array}$} & Sharing photos, videos or posts & 139 & 9,2 \\
\hline & Following My Friends'Shares & 398 & 26,4 \\
\hline & Following The Agenda & 665 & 44,1 \\
\hline & Communicating With My Friends & 147 & 9,7 \\
\hline & Other & 23 & 1,5 \\
\hline & Not Use & 137 & 9,1 \\
\hline
\end{tabular}


The Use of Social Networks and the Need for Social Approval of People in the Fields...

Table 4: Comparison of Demographic Characteristics and the Need Social Approval

\begin{tabular}{|c|c|c|c|c|c|c|c|c|}
\hline \multirow[b]{2}{*}{ Variables } & \multicolumn{2}{|c|}{$\begin{array}{c}\text { Being Sensitive to } \\
\text { the judgments of } \\
\text { others }\end{array}$} & \multicolumn{2}{|c|}{ Social Withdrawal } & \multicolumn{2}{|c|}{$\begin{array}{l}\text { Leave a positive } \\
\text { impression }\end{array}$} & \multicolumn{2}{|c|}{ General } \\
\hline & M & SD & $\mathbf{M}$ & SD & $\mathbf{M}$ & SD & M & SD \\
\hline \multicolumn{9}{|l|}{ Gender } \\
\hline Female & 28,1313 & $5,87726^{a}$ & 18,8380 & $5,13744^{b}$ & 21,1341 & $5,70696^{a}$ & 68,1034 & $15,07039^{b}$ \\
\hline Male & 28,6544 & 6,32129 & 19,0467 & 5,03138 & 20,2434 & 5,49610 & 67,9445 & 14,94888 \\
\hline \multicolumn{9}{|l|}{ Age } \\
\hline $18-24$ & 30,4466 & $5,65812^{a}$ & 19,4660 & $5,41750^{\mathrm{a}}$ & 21,6117 & $5,74325^{a}$ & 71,5243 & $14,90022^{\mathrm{a}}$ \\
\hline $25-34$ & 28,8139 & 5,65825 & 19,3461 & 4,88904 & 21,1791 & 5,55846 & 69,3391 & 14,25739 \\
\hline $35-44$ & 27,7378 & 6,48164 & 18,8774 & 5,30208 & 20,4228 & 5,71376 & 67,0381 & 15,82139 \\
\hline $45-54$ & 27,4688 & 6,27250 & 17,9688 & 4,99721 & 19,7723 & 5,58240 & 65,2098 & 15,20018 \\
\hline $55-64$ & 28,7500 & 6,43283 & 18,3800 & 4,85087 & 19,8600 & 5,17379 & 66,9900 & 14,28038 \\
\hline $65+$ & 29,7941 & 5,76184 & 19,7353 & 4,49450 & 20,7647 & 5,18190 & 70,2941 & 12,82405 \\
\hline \multicolumn{9}{|l|}{ Education } \\
\hline Undergraduate & 28,3923 & $6,12291^{b}$ & 18,7845 & $4,97556^{b}$ & 20,3906 & $5,54019^{b}$ & 67,5673 & $14,67729^{b}$ \\
\hline Graduate & 28,6096 & 5,96033 & 19,1070 & 5,29194 & 20,8957 & 5,82611 & 68,6123 & 15,26168 \\
\hline Dissertation & 28,2810 & 6,22737 & 19,0166 & 5,05211 & 20,8096 & 5,53965 & 68,1072 & 15,18429 \\
\hline \multicolumn{9}{|l|}{ Profession } \\
\hline Doctor & 28,6884 & $6,18427^{a}$ & 19,7508 & $5,29483^{a}$ & 21,5395 & $5,88131^{a}$ & 69,9787 & $15,77504^{\mathrm{a}}$ \\
\hline Judge & 26,3400 & 6,24536 & 16,9200 & 4,55282 & 18,7600 & 5,34736 & 62,0200 & 14,25638 \\
\hline Lawyer & 28,3158 & 6,06940 & 18,3041 & 4,76858 & 19,8674 & 5,28910 & 66,4873 & 14,02677 \\
\hline Professor & 28,2054 & 5,66821 & 18,5804 & 4,94772 & 20,2143 & 4,97639 & 67,0000 & 13,41708 \\
\hline $\begin{array}{l}\text { Research } \\
\text { Assistant }\end{array}$ & 28,3295 & 6,19072 & 18,6307 & 4,93790 & 20,5568 & 5,49048 & 67,5170 & 15,02796 \\
\hline
\end{tabular}

${ }^{\mathrm{a} p}<0.05$

${ }^{\mathrm{b}} \mathrm{p}>0,05$ 
Table 5: Comparison of Use of Social Networks and the Need for Social Approval

\begin{tabular}{|l|c|c|c|c|c|c|}
\hline & \multicolumn{4}{|c|}{ The Need for Social Approval } \\
\hline Variables & N & M & SD & Min. & Max. & p \\
\hline The Purpose of Internet Use & & & & & \\
\hline Entering Social Networks & 509 & 71,6326 & 14,93294 & 31,00 & 121,00 \\
\hline Researching and Getting Information & 723 & 65,3029 & 14,83812 & 25,00 & 109,00 \\
\hline Surfing on the Internet & 185 & 70,3892 & 14,47561 & 27,00 & 107,00 \\
\hline Playing Game & 35 & 64,9429 & 12,26891 & 40,00 & 98,00 \\
\hline Other & 57 & 64,4211 & 12,94211 & 34,00 & 94,00 \\
\hline The Purpose Of Using Social Networks & & & & & \\
\hline Sharing photos, videos or posts & 139 & 68,6691 & 14,63042 & 33,00 & 101,00 \\
\hline Following My Friends' Shares & 398 & 72,4347 & 14,79020 & 29,00 & 107,00 \\
\hline Following The Agenda & 665 & 65,9835 & 15,00606 & 25,00 & 121,00 \\
\hline Communicating With My Friends & 147 & 66,2857 & 13,00895 & 31,00 & 96,00 \\
\hline Other & 23 & 68,0870 & 13,97372 & 37,00 & 91,00 \\
\hline Not Use & 137 & 66,2701 & 15,58728 & 25,00 & 109,00 \\
\hline Number Of Social Networks Used & & & & & \\
\hline 1 & 450 & 67,4378 & 14,57389 & 25,00 & 107,00 \\
\hline 2 & 556 & 67,2482 & 15,39848 & 25,00 & 107,00 \\
\hline 3 & 255 & 70,7922 & 14,68568 & 29,00 & 100,00 \\
\hline 4 & 61 & 68,1967 & 14,13485 & 35,00 & 101,00 \\
\hline More than 4 & 44 & 73,3409 & 13,89653 & 49,00 & 121,00 \\
\hline Not Use & 143 & 66,1958 & 15,28659 & 25,00 & 109,00 \\
\hline
\end{tabular}


